\title{
Socio-Economic, Personal and Psychological Characteristics Affecting Entrepreneurial Intention of Agricultural Students
}

\author{
Amita Yadav* and S.K. Kashyap \\ Department of Agricultural Communication, Govind Ballabh Pant University of \\ Agriculture and Technology, Pantnagar- 263145 (Uttarakhand), India \\ *Corresponding author
}

\begin{tabular}{|c|c|}
\hline \multicolumn{2}{|r|}{ A B S T RA C T } \\
\hline & \multirow{6}{*}{$\begin{array}{l}\text { India has been one of the fastest growing economies of the world since the } 1980 \text { s. } \\
\text { But still unemployment among graduates is very serious concern. Many fresh } \\
\text { graduates do possess the knowledge and skill that are important for starting-up } \\
\text { own business. However, only a tiny percentage of students choose to be self- } \\
\text { employed after graduation. The study was conducted at College of Agriculture, } \\
\text { G.B.P.U.A. \& T. Pantnagar to study the relationship between with socio- } \\
\text { economic, personal, and psychological variables with entrepreneurial intention of } \\
\text { undergraduate students. Analytical research design was used for the present study. } \\
\text { Detailed pre-tested questionnaire was administered to } 110 \text { respondents for } \\
\text { collection of data. Results revealed that self-confidence, achievement motivation, } \\
\text { innovativeness were significantly positively correlated with entrepreneurial } \\
\text { intention. On the other hand family size, total family income, occupation of head } \\
\text { of the family and risk taking ability had non-significant positive relationship with } \\
\text { entrepreneurial intention but academic performance had non-significant negative } \\
\text { correlation with entrepreneurial intention. }\end{array}$} \\
\hline Keywords & \\
\hline $\begin{array}{l}\text { Entrepreneurial } \\
\text { Intention, } \\
\text { Entrepreneurship, } \\
\text { Agriculture, } \\
\text { Correlation. }\end{array}$ & \\
\hline Article & \\
\hline $\begin{array}{l}\text { Accepted: } \\
\text { 21 June } 2017 \\
\text { Available Online: } \\
\text { 10 July } 2017\end{array}$ & \\
\hline & \\
\hline
\end{tabular}

\section{Introduction}

Entrepreneurship is seen as a critical factor in promoting innovation, creating employment opportunities and generating social and economic wealth in a country's economy (Wong et al., 2005). Entrepreneurship has been recognized as an important element in the dynamics of modern economies. Entrepreneurship which can be understood as "the mindset and process to create and develop economic activity" has significantly raised interest among practitioners, scientists and politicians over the last decades (Davey et al., 2009). Entrepreneurship is a prerequisite for the development of any nation as it plays a great role in the economic growth and development of the country, more so in rapidly developing countries.

The basic concept of entrepreneurship connotes effectiveness or an urge to take risk in the face of uncertainties. Various concepts and theories propounded by researchers indicate that the emergence of an entrepreneur depends upon closely interlinked economic, social, cultural, religious and psychological variables. Many definitions can be found in 
the literature, however, a generally accepted and popular definition for entrepreneurship is that "entrepreneurship is process that involves the discovery, evaluation, and exploitation of opportunities to introduce new products, services, processes, ways of organizing, or markets" (Shane and Venkataraman, 2000).

\section{Entrepreneurial intention}

Entrepreneurial intention is typically considered to be formed by a person's attitude toward entrepreneurship and the prevailing social norms attached to entrepreneurship in the future (Krueger et al., 2000). Thus, entrepreneurial intention is a conscious state of mind that directs attention toward a specific object (goal). There are numerous interconnections between attitudes and various interrelated objects. Shepherd and Douglas (1997) examined people who are in the process of choosing between career alternatives and expect these attitudes are associated with the degree of intention to become an entrepreneur. These attitudes were those toward independence, financial risk, hard work and income. While 'positive' attitudes towards all four of these objects should be expected to generate an intention to undertake entrepreneurial activity.

Ibrahim and Soufani (2002) stated that university curricula should focus on encouraging autonomy and independence, innovation and creativity, as well as risktaking. Entrepreneurship knowledge and skills can be learned from entrepreneurship courses at the university level and through the introduction of these concepts at secondary schools and places of higher education.

We are producing more literates and not trained youth to earn their own bread. Our graduates in Agriculture and allied sectors are emerging as job-seekers. By giving them entrepreneurial training we may make them as job givers. This will be their elevation from "Learned Graduates to Agricultural Entrepreneurs". Fostering entrepreneurship among students has become an important topic in universities as well as for government. Positive role of universities in developing entrepreneurial intention and to explore the factors influencing entrepreneurial behaviour of students that help to explain the emergence of entrepreneurial intention among target groups as well as suggest the stimulation of entrepreneurship education that can influence the students' attitude and intention towards entrepreneurship. The introduction of entrepreneurship programs to the college students would enhance students' attributes and further develop awareness of entrepreneurial opportunities and skills to form entrepreneurial ventures.

The present study was conducted to fulfill the objective i.e. to study the relationship, if any, between selected socio- economic, personal and psychological characteristics of undergraduate students of agriculture and their entrepreneurial intention.

\section{Materials and Methods}

The present study was focused on assessing the relationship between selected socioeconomic, personal and psychological characteristics of undergraduate students of agriculture and their entrepreneurial intention. So population frame for the present study included all the agricultural universities and institutions of country which are offering graduation in agriculture. However, College of Agriculture, G. B. Pant University of Agriculture and Technology, Pantnagar, Udham Singh Nagar district of Uttarakhand state was purposively selected which constituted the locale of the present study because the locale in which this study was conducted is the premier agricultural institute of the country which is first Agriculture 
University established in India and takes pride as initiator of Practical Crop Production course in order to give direct experience in sowing, cultivation, and cost benefit analysis of crops. Students not only earn while they learn but are also exposed to various facets of rural life and work situation through attachment to village and agro-industrial organization as well as participation in plant clinic laboratories and field work. The present study was done at College of Agriculture. Fifty per cent students from each, third and fourth year of B.Sc. Agriculture were selected as respondents through Simple Random Sampling Technique by using chit method to draw sample. Total 110 respondents were selected for collection of data. Analytical research design was used for the present study. Detailed pre-tested questionnaire was administered to respondents. (Kothari, C.R. 1990. Research methodology: Methods and Techniques. New Age International, Delhi).

After deep analysis of various theories and review of literature on available career prospects, age, gender, caste, medium of basic education, academic performance, family size, family type, family background, total family income, occupation of head of the family, self-confidence, achievement motivation, innovativeness and risk taking ability were taken as independent variables in the present study. Entrepreneurial intention of undergraduate students of agriculture was taken as the dependent variable.

\section{Results and Discussion}

The coefficient of correlation was calculated to find out the relationship between selected socio-economic, personal and psychological characteristics of the students with entrepreneurial intention of students and the significance of coefficient of correlation was tested using t-test.
The effect of selected socio-economic, personal and psychological characteristics comprising academic performance, family size, total family income, occupation of head of the family, self-confidence, achievement motivation, innovativeness and risk taking ability on entrepreneurial intention of undergraduate students was calculated and is presented in table 1 .

The data presented in table 1 revealed that academic performance was found to be nonsignificant and negative relationship with entrepreneurial intention of undergraduate students of agriculture. The negative correlation indicates that increase in Cumulative Grade Point Average (CGPA) leads to decrease in entrepreneurial intention. Hence, null hypothesis $\mathrm{H}_{0 \mathrm{~A}}$ was accepted. The negative relationship between academic performance and entrepreneurial intention of undergraduate students may be due to the fact that students with high (CGPA) Cumulative Grade Point Average prefer to go for higher studies and want to establish their career in academics. They also have a greater chance of getting employment with good salaried job. Findings of the present study are in line with the findings of Sharma and Madan (2014) who reported that respondents who were placed in the 'High category' on academic intelligence were seen to be less inclined towards taking up entrepreneurship as a career.

It is clear from table 1 that family size had non-significant positive relationship with entrepreneurial intention of undergraduate students of agriculture. Hence, null hypothesis $\mathrm{H}_{0 \mathrm{~B}}$ was accepted. It is inferred from the results that it did not affect the intention of students whether they belonged to large or small family size.

The value of coefficient of correlation at $1 \%$ level of significance in table 1 clearly reflects 
a non-significant positive relationship between total family income and entrepreneurial intention of undergraduate students of agriculture. Hence, null hypothesis $\mathrm{H}_{0 \mathrm{C}}$ was accepted. The reason behind this could be the availability of financial support from various sources which enable an individual to start his/her enterprise. Financial status of the family does not have much bearing on entrepreneurship development as they can get loan from banks and start a new venture. The findings of present study are in line with that of Ali et al., (2012) who reported that family income did not have any positive impact on entrepreneurial intention and students belonging to low income families were more willing to be an entrepreneur.

It is evident from table 1 that occupation of head of the family had non-significant positive relationship with entrepreneurial intention of undergraduate students of agriculture. Hence, null hypothesis $\mathrm{H}_{0 \mathrm{D}}$ was accepted. It infers that family occupation does not make significant impact on the individual career decision of the students now after their varied exposure during professional studies.

The data presented in table 1 shows significant positive relationship between selfconfidence and entrepreneurial intention of undergraduate students of agriculture. Hence, null hypothesis $\mathrm{H}_{0 \mathrm{E}}$ was rejected. Selfconfidence is one of important trait of an entrepreneur that generates the ability to take risk while starting any new business. Students with low self-confidence always seek secured and safe job and don't want to get into entrepreneurship. This finding is supported by earlier study by Ashraf and Rasoul (2013) where it was found that self-confidence had significant positive influence on entrepreneurial intention of students.

Table.1 Correlation analysis between selected independent variables and Entrepreneurial intention

\begin{tabular}{|c|c|c|c|}
\hline \multirow{2}{*}{$\begin{array}{l}\text { S. } \\
\text { No. }\end{array}$} & \multirow[t]{2}{*}{ Independent Variables } & \multicolumn{2}{|c|}{ Dependent variable (entrepreneurial intention) } \\
\hline & & Correlation coefficient ( $r$ value) & 't' value \\
\hline 1. & Academic performance & -0.1823 & $-1.9595 \mathrm{NS}$ \\
\hline 2. & Family size & 0.1138 & $1.1980 \mathrm{NS}$ \\
\hline 3. & Total family income & 0.0556 & $0.5795 \mathrm{NS}$ \\
\hline 4. & Occupation of head of the family & 0.0372 & $-0.3870 \mathrm{NS}$ \\
\hline 5. & Self confidence & $0.2728 * *$ & 3.0628 \\
\hline 6. & Achievement motivation & $0.2582 * *$ & 2.8746 \\
\hline 7. & Innovativeness & $0.3095 * *$ & 3.5567 \\
\hline 8. & Risk taking ability & 0.0912 & $0.9556 \mathrm{NS}$ \\
\hline
\end{tabular}

Results regarding achievement motivation in table 1 indicate a significant positive relationship between achievement motivation and entrepreneurial intention of undergraduate students of agriculture. Hence, null hypothesis $\mathrm{H}_{0 \mathrm{~F}}$ was rejected. This significant positive relationship establishes the fact that achievement motivation encourages people to fulfill their ambitions and therefore, emerge as an important factor in building confidence to take decision in favour of entrepreneurship. People with low achievement motivation can't take leap to go for entrepreneurship and therefore, lack of 
achievement motivation becomes a detrimental factor for positive entrepreneurial intention.

Picture remains the same as it indicates a significant positive relationship between innovativeness and entrepreneurial intention of undergraduate students of agriculture. Hence, null hypothesis $\mathrm{H}_{0 \mathrm{G}}$ was rejected. It is similar to the findings of Gurol and Astan (2006), where innovativeness had a significant positive relationship with entrepreneurial intention.

The findings show that students with low innovativeness opt less for entrepreneurship and wish to go for secured jobs whereas those, with high level of innovativeness feel comfortable in opting for entrepreneurship where they may get a chance to try something new and get more challenges. Innovative students get successful in agri-entrepreneurial ventures more frequently as is established by cases of agri-entrepreneurs of the country and the world. Therefore, it seems essential to generate this trait in agriculture graduates through regular interventions so that they emerge more venturesome.

It is evident from table 1 that risk taking ability had non-significant positive relationship with entrepreneurial intention of undergraduate students of agriculture. Hence, null hypothesis $\mathrm{H}_{0 \mathrm{H}}$ was accepted. This finding is similar to the finding of the study conducted by Altinay et al., (2012) where it was found that risk taking ability had no significant relationship with entrepreneurial intention due to effect of family background. At the same time it contradicts finding of the study conducted by Nishantha (2009), Gurel et al., (2010) and Rona (2011) where a significant positive relationship between the two variables was reported.

In conclusion, Findings of the present study showed that self-confidence, achievement motivation, and innovativeness were found to have significant positive relation with entrepreneurial intention. It categorically emphasizes the importance of self-confidence, achievement motivation, and innovativeness in generating entrepreneurial capability among students. Inculcation of these traits in undergraduate students becomes indispensible for the institution if entrepreneurial intention has to be inculcated and enhanced in the students at university level. Special attention, efforts and emphasis need to be taken on regular basis so that the students of agriculture may get psychologically prepared to generate high entrepreneurial intention by their initial year of studies. Entrepreneurship is a way of thinking that emphasizes opportunities over threats. The opportunity identification process is clearly an intentional process, and therefore, entrepreneurial intentions clearly merit one's attention. Entrepreneurial intention is also considered to be the first step in new business formation. Graduate employment gap needs to be filled through entrepreneurship. Amidst the changing paradigms and demanding global structure, India, in order to remain a front runner needs to primarily focus on the agriculture sector, the backbone of the economy. This specialization will develop agricultural entrepreneurs with distinct traits and skills to exploit opportunities galore in field of agriculture. Among the various strategies to promote planned growth in this sector, focus on promoting viable enterprises will certainly help exploit its operational efficiency to the hilt.

\section{References}

Ali, S., Lu, Wei.and Wang, W. 2012. Determinants of entrepreneurial intentions among the college students in: China and Pakistan. Journal of Education and Practice, 3 (11): 13-22.

Altinay, L., Madanoglu, M., Daniele, R. and Lashley, C. 2012. The influence of 
family tradition and psychological traits on entrepreneurial intention. International Journal of Hospitality Management, 31(2): 489- 499.

Ashraf S. and Rasoul, I. 2013. Factors Affecting Entrepreneurial Attitudes of MA Students in Islamic Azad University. International Journal of Advanced Studies in Humanities and Social Science, 1 (5): 485-491.

Davey T., Plewa C. and Kliewe, T. 2009. Attitudes to entrepreneurship: what do $1^{\text {st }}$ year business students think? Areas of focus and improvement for universities in promoting and supporting students' entrepreneurship. Proceedings of the Sixth Annual AGSE International Entrepreneurship and Innovation Research Exchange, 2009: pp.1267-1282.

Gurel, E., Altinay, L., Daniele, R., 2010.Tourism students' entrepreneurial intentions. Annals of Tourism Research, 37 (3): 646-669.

Gurol, Y. and Atsan, N. 2006. Entrepreneurial characteristics amongst university students: some insights for entrepreneurship education and training in Turkey. Education and Training, 48(1): 25-38.

Ibrahim A B, Soufani K. 2002. Entrepreneurship Education and Training in Canada: A Critical Assessment. Education and training, 44 (8/9): 421-430.

Kothari, C.R. 1990. Research methodology: Methods and Techniques. New Age International, Delhi.
Krueger, N. F. Jr., Reilly, M. D., and Carsrud, A. L. 2000. Competing Model of Entrepreneurial Intentions. Journal of Business Venturing, 15(5-6): 411-432.

Nishantha, B. 2009. Influence of personality traits and socio-demographic background of undergraduate students on motivation for entrepreneurial career: the case of Sri Lanka. Journal of Enterprising Culture, 49 (2): 71-82.

Rona, C.Y.Y. 2011. Born-global entrepreneurship intentions of undergraduate students. An Honours Degree Project Submitted to the School of Business in Partial Fulfillment of the Graduation Requirement for the Degree of Bachelor of Business Administration (Honours).Hong Kong Baptist University.

Shane, S., Venkataraman, S. 2000. The promise of entrepreneurship as a field of research. Academy of Management Review, 26 (1): 13-17.

Sharma, L. and Madan, P. 2014. Effect of individual factors on youth entrepreneurship- A study of Uttarakhand state, India. Journal of Global Entrepreneurship Research, 2 (3): 26-50.

Shepherd DA, Douglas E (1997) Entrepreneurial Attitudes and Intentions of Career Decision Maker. Working Paper.

Wong, P. K., Ho, Y. P. and Autio, E. 2005. Entrepreneurship, innovation and economic growth: Evidence from GEM data. Small Business Economics, 24 (3): 335-350.

\section{How to cite this article:}

Amita Yadav and Kashyap, S.K. 2017. Socio-Economic, Personal and Psychological Characteristics Affecting Entrepreneurial Intention of Agricultural Students. Int.J.Curr.Microbiol.App.Sci. 6(7): 2241-2246. doi: https://doi.org/10.20546/ijcmas.2017.607.263 